\title{
Color Parameters to Predict Moisture and Tannin Content in Yerba Mate Process
}

\author{
Catia Nara Tobaldini Frizon ${ }^{1}$ [1 0000-0002-0828-6037 \\ Silvana Nisgoski ${ }^{1}$ (1) 0000-0001-9595-9131
}

\begin{abstract}
This study evaluated color and reflectance spectra during industrial process of yerba mate leaves and tested the potential of these parameters to predict moisture and tannin content, to be applied as an auxiliary tool in quality control in industry. Two groups of yerba mate samples were evaluated: one grown under organic and another under conventional conditions. The results indicate an increase in lightness, loss of the green color, although less marked in the organic samples, an increase of yellow in both types of samples along processing due to moisture removal at high temperatures. For moisture content, reflectance curve can be applied with $\mathrm{R}^{2} \geq 0.9$, and for tannin content the sum of $\mathrm{b}^{*}$ parameter and spectra in region $590-700 \mathrm{~nm}$ are recommended. Color parameters and reflectance spectra can be applied for a preliminary evaluation of moisture and tannin content in the yerba mate industry, contributing for the quality control of samples.
\end{abstract}

Keywords: Ilex paraguariensis, industrial processing, leaves characteristics and prediction.

\section{INTRODUCTION AND OBJECTIVES}

Yerba mate color is a factor or characteristic that affects its marketing and quality, very important for consumer buying decision. The green color in leaves is related to chlorophyll content, a natural green pigment that occurs in major quantity and in almost all plants. In its chemical composition, there is a basic ring structure of phorbin and the addition of a 5-membered isocyclic rings produces variations. Chlorophyll a and $\mathrm{b}$ are the most known and are differentiated by a change of substituent groups on ring $B$ from methyl to formyl. These two forms coexist in plants, being chlorophyll a the most predominant and less stable, also presenting a bluer green character. In higher plants, chlorophylls and carotenoids absorb light in red and blue region in visible spectra, and the green light is the most reflected (İnanç, 2011).

Pigments in leaves are necessary for photosynthesis and to protect against stress in extreme light and temperatures (Ollinger, 2010). Physiological functions of leaves are related to pigments (Sims \& Gamon, 2002), being the absorbance of visible light the first step in photosynthesis (Richardson et al., 2003). In physiological reflectance of visible light, data at 430 and $445 \mathrm{~nm}$ indicate carotenoids; at 531 and $570 \mathrm{~nm}$ indicate xanthophylls, bands at $550-680 \mathrm{~nm}$, and a peak at $700 \mathrm{~nm}$ indicate chlorophyll (Peñuelas \& Filella, 1998). The reduction of $80 \%$ in chlorophyll content in yerba mate during bleaching was reported by Schmalko \& Alzamora (2001) and a positive correlation between green-red chromatic coordinate and decrease of chlorophyll content was related by Cabral-Malheiros et al. (2010).

In yerba mate, it is not only color that is important, but also the chemical composition of leaves that includes phenolic compounds, saponins, methylxanthines, sugars and vitamins (Blum-Silva et al., 2015; Burris et al., 2012; Hao et al., 2013; Polidoro et al., 2016). Tannin content present in yerba mate leaves are responsible for its astringency; a higher concentration of it was observed in plantations located in regions with more luminosity (Caron et al., 2014), and influence its color, which is also affected by process. Oxidation is one of the transformations that occur in leaves, being directly related to luminosity of the material (Valduga et al., 2016).

Moisture content control in yerba mate during process and storage contribute to its quality, avoiding, for example, the development of microorganisms related to degradation. Color, flavor and texture are the most important parameters in the

\footnotetext{
${ }^{1}$ Universidade Federal do Paraná (UFPR), Curitiba, PR, Brasil
} 
quality control of yerba mate; however, for final consumers, color is the first criteria (Ceni et al. 2009). Color preferences depends on the country; in Argentina, Paraguay and Uruguay consumers prefer a light olive green, which is obtained by a degradation of chlorophyll during process. In Brazil, on the other hand, a bright green is preferable (Scipioni et al., 2010).

Due to the facility and convenience of color analysis instead of chemical methods - usually the slowest and most spending - this research evaluated color and reflectance spectra variation during industrial process of yerba mate leaves and, as a preliminary study, to test the potential of these parameters to predict moisture and tannin content in each stage, as an auxiliary tool for quality control in the industry.

\section{MATERIALS AND METHODS}

\subsection{Plant material}

Two groups of yerba mate (Ilex paraguariensis) samples from the Southeastern state of Paraná, Brazil, were used as the plant material: one group $(\mathrm{n}=30)$ grown under organic conditions $\left(25^{\circ} 40^{\prime} 22^{\prime \prime} \mathrm{S}, 50^{\circ} 17^{\prime} 15^{\prime \prime} \mathrm{W}\right)$ certified by Ecocert Brasil (a company responsible for monitoring the growing and processing of organic yerba mate) and based on international standards, and another group $(\mathrm{n}=35)$ grown under conventional conditions ( $25^{\circ} 52^{\prime} 36^{\prime \prime} \mathrm{S}, 50^{\circ} 23^{\prime} 3^{\prime \prime} \mathrm{W}$ ). The climate in the region according to the Köeppen classification is temperate (Cfb) (Alvares et al., 2013), and the phytoecological unit is defined as Mixed Rain Forest (Roderjan et al., 2002).

We received samples from the same lot in different processing stages, namely: (1) Green leaves: natural leaves and thin branches harvested and sent to the laboratory for immediate analysis to preserve the chemical and physical characteristics of the plant; (2) Bleaching (zapeco): the yerba mate was burned for 2-3 minutes with the flame produced by burning wood at a temperature between 500 and $600{ }^{\circ} \mathrm{C}$, at which occurs the inactivation of oxidative enzymes, preserving color, aroma and flavor of leaves, and also near $25 \%$ of moisture content is lost; (3) Pre-drying: the bleached yerba mate is driven by belts to the pre-dryer, in which it is exposed to a temperature of $200^{\circ} \mathrm{C}$ for 3 minutes without direct contact with the flame. At the end of this stage, the leaves lost about $80 \%$ of their moisture; (4) Drying: the leaves are arranged on the conveyor belt so that the heat is proportional throughout its surface. The appropriate drying time and temperature range from 4 to 6 hours and 100 to $110{ }^{\circ} \mathrm{C}$, respectively; (5) Crumbling (cancheamento): the thicker stems and leaves are fragmented; (6) Natural storage: the product is stored under natural conditions - temperature around $18^{\circ} \mathrm{C}$ and relative humidity of $80 \%$ - for about 9 months; (7) Forced Storage: the product is stored under controlled conditions of temperature $\left(45^{\circ} \mathrm{C} \pm 2 \%\right)$, relative humidity $(31 \% \pm 2 \%)$ and air circulation for 90 days to acquire the desired flavor, aroma and color.

This study used five samples in each stage, seven for conventional yerba mate and six for organic yerba mate, for a total of 65 samples.

\subsection{Color measurement}

Color measurements of the commercial and organic samples $(\mathrm{n}=65)$ were performed using a CM-5 spectrophotometer with D65 light source and $10^{\circ}$ observation angle, operating in the CIELAB system. Readings were performed in five replications in each stage of industrial process, in material received from companies. The results were expressed as mean values of $L^{*}$ (lightness, $0=$ black and $100=$ white), chromatic coordinate $\mathrm{a}^{*}$ (green $(-\mathrm{a})$ to red $(+\mathrm{a})$ ) and $\mathrm{b}^{*}$ (blue $(-b)$ to yellow $(+b))$. Reflectance data in a spectral range of 400-750 nm was also obtained.

\subsection{Determination of total tannins}

Milled samples were used for this analysis, and the quantity of condensed tannin was determined by vanillin reaction according to the adapted Prince's method (Prince et al. 1978), which consists of one stage of tannin extraction from yerba mate with methyl alcohol, under agitation during one hour, followed by filtration. For such purpose, $5 \mathrm{~mL}$ of a newly prepared 1:1 solution of $1 \%$ vanillin in methyl alcohol and $4 \%$ hydrochloric acid in methyl alcohol was added to an aliquot of $1 \mathrm{~mL}$ of methanol extract, in a test tube agitated in vortex for 30 seconds. Then the test tubes were preheated in a water bath at $30^{\circ} \mathrm{C}$ for 30 minutes. The reaction was maintained protected from light for 20 minutes and then the absorbance was read at $500 \mathrm{~nm}$. The quantification was based on an external calibration curve employing tannic acid - ACS reagent (Sigma-Aldrich, 403040) as the standard and expressed in mg. $\mathrm{g}^{-1}$.

\subsection{Determination of moisture content}

Samples were dried in a kiln at $105^{\circ} \mathrm{C}$ until constant weight, according to the method 925.09 of the Association of Official Analytical Chemists (AOAC, 2005).

\subsection{Statistical analysis}

The color parameters $\left(L^{\star}, a^{\star}, b^{\star}\right)$ were evaluated using descriptive statistics and regression analysis. Moreover, the Tukey's test was performed with $95 \%$ probability to verify the possible grouping of process stage in each parameter. 
To evaluate data, a Partial Least Square (PLS) modeling, based on the NIPALS algorithm and cross validation was performed in The Unscrambler X chemometric program (version 10.1, from CAMO Software AS). To obtain multivariate models with good prediction capacity, a pretreatment of first derivative (polynomial order $=2$, smoothing point $=3$ ) and second derivative of SavitzyGolay (polynomial order $=2$, smoothing point $=5$ ) were applied to the reflectance spectra. The PLS models were evaluated using RMSEC (root mean square error of calibration), RMSEP (root mean square error of prediction) and their respective regression coefficients. Generally, an adequate model must have high regression coefficients and low RMSEC and RMSEP values.

Pretreatments are important to eliminate noise and improve the posterior analysis. Savitzky-Golay derivation includes a smoothing step and can remove additive and multiplicative effects. Partial Least Square Analysis (PLS) is frequently applied in multivariate calibration (Tan et al., 2012) and was performed to build calibration models for moisture and tannin content in different process stage of organic and conventional yerba mate. The number of principal components (PCs) is the most important information, which is included in regression models to result in lower prediction error. Data were evaluated by cross validation, which involves an observation from the original sample considered as data validation, with the remaining observations being considered as training data. This process was repeated until all samples were applied one time for validation set (Xie et al., 2007). The leave-one-out/ cross validation procedure was indicated, since it does not leave out samples (all samples were applied in model building), and because it is more adequate for a small number of samples.

\section{RESULTS AND DISCUSSION}

\subsection{Color and reflectance variation}

Average values of $\mathrm{L}^{*}, \mathrm{a}^{*}$ and $\mathrm{b}^{*}$ in conventional and organic yerba mate samples obtained at different stages of industrial processing are shown in Table 1.
Results showed that $\mathrm{L}^{*}$ increased significantly $(p<0.05)$ in samples of conventional and organic yerba mate during processing. In the scale of $L^{*}$, when values are closer to 0 , the product is darker, and the values closer to 100 represent a lighter or whiter product. Therefore, the lightness of conventional and organic samples was affected by the thermal treatment and had an increase in values with the increase in the intensity of treatment. This effect was expected due to the rapid moisture loss of yerba mate leaves exposed to high temperatures, being lighter. This result is different from Schmalko \& Alzamora (2001), who observed little distinction in $\mathrm{L}^{\star}$ from green and processed leaves. Valduga et al. (2005) reported an increase in luminosity with time of storage.

The values found for $\mathrm{a}^{\star}$ and $\mathrm{b}^{\star}$ were respectively negative (correspondent to green) and positive (correspondent to yellow). The comparison of means performed by the Tukey's test $(p<0.05)$ showed that the parameter $-\mathrm{a}^{\star}$ was significantly different between samples. The results indicate the leaves tend to loss the green color, although less marked in the organic samples, which remained at negative values during natural storage. The chromatic coordinate $b^{*}$ increased significantly in both types of yerba mate along processing due to yellowing and moisture removal at high temperatures. However, the grinding comprised in the stage of crumbling considerably affected the values of $\mathrm{a}^{*}$. In other studies, large differences were observed in $\mathrm{a}^{*}$ and $\mathrm{b}^{*}$ parameters after bleaching, from -9.13 to -5.46 and from 17 to 21, respectively (Schmalko \& Alzamora, 2001), and storage time contributed to reduce the green color (Valduga et al., 2005).

Color is one of the consumer's acceptance attributes used for yerba mate. In Brazil, there is a preference of bright green yerba mate, whereas in other countries of South America (Argentina, Paraguay and Uruguay) the preference is for olive to goldenyellow (Valduga et al., 2005). The green color of yerba mate is ascribed to the presence of chlorophyll, which is significantly lost during processing and storage. Each stage of the manufacturing process is responsible for the reduction of this component. The literature reports that the drying temperature influences $\mathrm{L}^{*}$ and $\mathrm{b}^{*}$ coordinates and the most important variation occurs between $80-100^{\circ} \mathrm{C}$ (Ramallo et al., 2010).

Table 1. Average values of $\mathrm{L}^{*}, \mathrm{a}^{\star}$ and $\mathrm{b}^{*}$ in conventional and organic yerba mate samples obtained at different stages of industrial processing.

\begin{tabular}{|c|c|c|c|c|c|c|}
\hline \multirow{2}{*}{$\begin{array}{l}\text { Processing } \\
\text { stage }\end{array}$} & \multicolumn{3}{|c|}{ Conventional yerba mate } & \multicolumn{3}{|c|}{ Organic yerba mate } \\
\hline & $\mathbf{L}^{*}$ & $\mathbf{a}^{\star}$ & $\mathbf{b}^{*}$ & $\mathbf{L}^{*}$ & $\mathbf{a}^{\star}$ & $\mathbf{b}^{*}$ \\
\hline Green leaves & $30.97 \pm 2.80^{\mathrm{a}}$ & $-4.48 \pm 1.16^{c}$ & $7.92 \pm 2.05^{\mathrm{a}}$ & $32.94 \pm 2.24^{\mathrm{a}}$ & $-8.50 \pm 0.69^{a}$ & $15.07 \pm 2.55^{\mathrm{a}}$ \\
\hline Bleaching & $39.64 \pm 3.75^{\mathrm{b}}$ & $-6.04 \pm 1.31^{\mathrm{a}}$ & $19.52 \pm 2.93^{c}$ & $47.82 \pm 2.61^{\mathrm{d}}$ & $-7.96 \pm 0.66^{\mathrm{a}}$ & $22.34 \pm 2.44^{c}$ \\
\hline Pre-drying & $38.97 \pm 2.59^{b}$ & $-5.45 \pm 0.83^{\mathrm{b}}$ & $17.87 \pm 1.87^{\mathrm{b}}$ & $48.84 \pm 2.29^{\mathrm{e}}$ & $-5.30 \pm 1.13^{c}$ & $31.59 \pm 3.77^{\mathrm{e}}$ \\
\hline Drying & $41.04 \pm 2.60^{c}$ & $-6.08 \pm 0.81^{\mathrm{a}}$ & $20.96 \pm 3.13^{\mathrm{d}}$ & $44.90 \pm 0.89^{c}$ & $-7.17 \pm 0.22^{b}$ & $26.57 \pm 0.84^{\mathrm{d}}$ \\
\hline Crumbling & $41.21 \pm 1.42^{c}$ & $-3.49 \pm 0.65^{\mathrm{d}}$ & $19.09 \pm 1.13^{b}$ & $39.59 \pm 2.37^{b}$ & $-3.92 \pm 1.74^{\mathrm{d}}$ & $18.13 \pm 1.51^{\mathrm{b}}$ \\
\hline Natural Storage & $45.76 \pm 1.71^{\mathrm{e}}$ & $0.12 \pm 0.47^{\mathrm{e}}$ & $21.06 \pm 1.20^{\mathrm{d}}$ & $47.40 \pm 0.87^{\mathrm{d}}$ & $-2.03 \pm 0.19^{\mathrm{e}}$ & $21.38 \pm 0.42^{c}$ \\
\hline Forced Storage & $44.13 \pm 1.80^{\mathrm{d}}$ & $0.59 \pm 0.54^{\mathrm{e}}$ & $20.15 \pm 1.11^{\mathrm{c}}$ & NR & NR & NR \\
\hline
\end{tabular}

$\mathrm{L}^{*}$ : lightness; $\mathrm{a}^{*}$ : red; $-\mathrm{a}^{*}$ : green, $\mathrm{b}^{*}$ : yellow; $-\mathrm{b}^{*}$ : blue. Means followed by the same letters in the same column are not significantly different according to the Tukey's test $(p<0.05)$. NR: stage not performed by the organic yerba mate company. 
Some authors indicate the influence of color parameters in teas. Jin et al. (2016) verified no correlations between color parameters and antioxidant properties when evaluating 110 herbal teas in China, and Zielinski et al. (2014) observed correlation between flavonoid content and parameters $\mathrm{L}^{*}$ and $\mathrm{a}^{*}$, with low coefficient of determination $\left(\mathrm{R}^{2}\right), 17.64 \%$ and $31.36 \%$ respectively.

The reflectance curve of the conventional and organic samples in each process stage are shown in Figure 1. The most important wavelengths that carry the essential color information of conventional and organic yerba mate were selected. According to Martins et al. (2015) green and yellow absorb light at the wavelengths of 500-565 nm and $565-590 \mathrm{~nm}$, respectively. The behavior of color during processing of the organic samples, represented by dotted lines, was more intense than in conventional ones (solid lines).

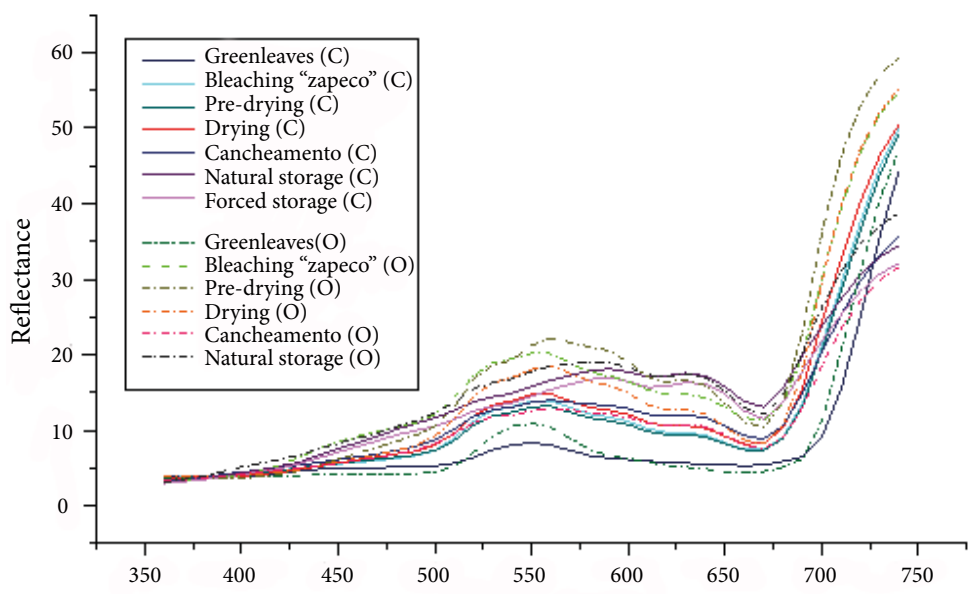

Figure 1. Reflectance in visible wavelength of yerba mate in different stages of processing for conventional $(\mathrm{C})$ and organic $(\mathrm{O})$ samples.

\subsection{Prediction of moisture content}

Mean moisture content (Table 2) ranged from $60.62 \%$ (green leaves) to $5.21 \%$ (forced storage) in conventional yerba mate samples, and from $65.27 \%$ (green leaves) to $5.05 \%$ (natural storage) in organic samples.

Data from color parameters, i.e., $\mathrm{L}^{*} \mathrm{a}^{*} \mathrm{~b}^{*}$ and reflectance curve (Figure 2), were applied to a Partial Least Square analysis to predict moisture content in different stage of processing. Cross validation was evaluated with original data, first and second derivative of Savitzky-Golay (Table 3).

In both PLS graphic, i.e., with data from $L^{\star} a^{*} b^{\star}$ and reflectance spectra, each stage of processing can be observed in conventional and organic yerba mate. Grouping is based on moisture content of each stage, showing the technique efficiency.
Color parameters resulted in a model with $\mathrm{R}^{2}=0.61$ and an error of $12-13 \%$ and second derivative of reflectance spectra presented $\mathrm{R}^{2}=0.95$ and error of $4-6 \%$, in a range of $5-65 \%$ of moisture content. Data for model building were obtained from two groups of plantations, organic and conventional, and in different stages. Moreover, the moisture content ranged from 5.05 to $65.27 \%$. Better regression model (Figure 3a) was with second derivative spectra, and green leaves, which present high moisture content, are far from other stages, which are similar. By observing loading graphs (Figure $3 \mathrm{~b}$ ), it is possible to verify wavenumbers with more influence in it: i) region from $495-589 \mathrm{~nm}$, which are related to green and yellow color; ii) region from $670-700 \mathrm{~nm}$, which is attributed to red color

Table 2. Mean moisture content of yerba mate samples in each process stage.

\begin{tabular}{|c|c|c|c|c|}
\hline \multirow{2}{*}{ Processing stage } & \multicolumn{2}{|c|}{ Conventional yerba mate } & \multicolumn{2}{|c|}{ Organic yerba mate } \\
\hline & Moisture Content (\%) & Standard deviation & Moisture Content (\%) & Standard deviation \\
\hline Green leaves & 60.62 & 1.7 & 65.27 & 2.0 \\
\hline Bleaching & 6.39 & 0.6 & 7.96 & 0.2 \\
\hline Pre-drying & 7.11 & 0.5 & 8.15 & 0.8 \\
\hline Drying & 6.08 & 0.1 & 7.89 & 0.6 \\
\hline Crumbling & 7.06 & 0.3 & 6.45 & 0.5 \\
\hline Natural Storage & 5.94 & 0.3 & 5.05 & 0.8 \\
\hline Forced Storage & 5.21 & 0.4 & Not a & cable \\
\hline
\end{tabular}



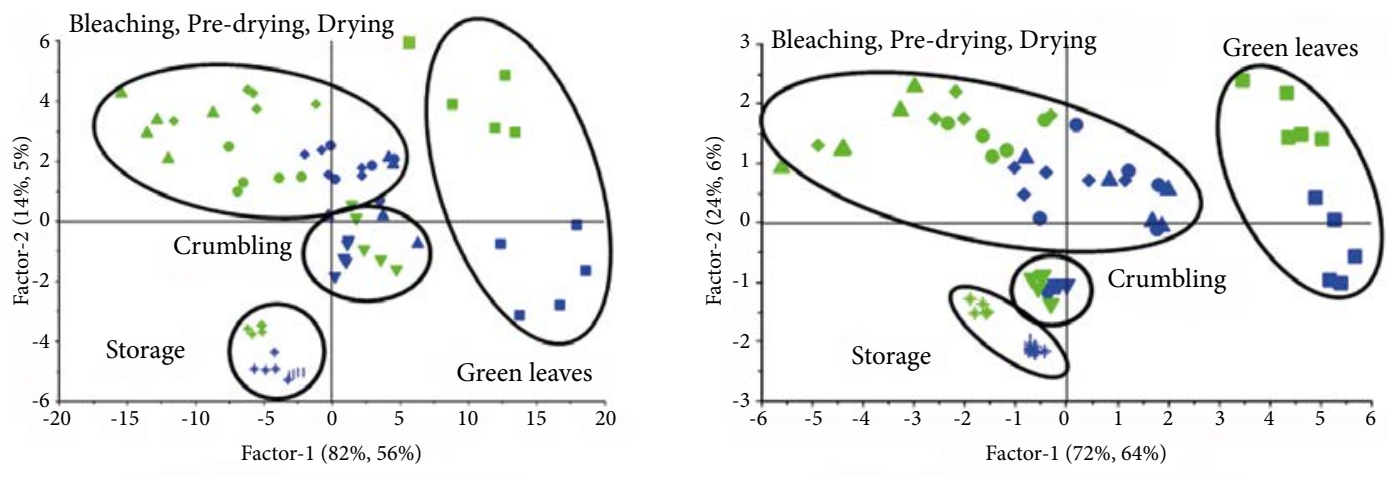

Moisture content $\mathrm{x} \mathrm{L} \mathrm{a}^{*} \mathrm{~b}^{*}$

Moisture content x Reflectance spectra

Figure 2. PLS graphic from $L^{\star} a^{*} b^{*}$ and reflectance spectra versus moisture content of conventional (blue) and organic (green) yerba mate samples.

Table 3. PLS model for moisture content prediction in yerba mate samples (conventional and organic) based on color parameters.

\begin{tabular}{|c|c|c|c|c|c|c|c|}
\hline \multirow{2}{*}{ Data } & \multirow{2}{*}{$\begin{array}{l}\text { Number of } \\
\text { PCs }\end{array}$} & \multicolumn{3}{|c|}{ Calibration } & \multicolumn{3}{|c|}{ Validation } \\
\hline & & Correlation & $\mathbf{R}^{2}$ & RMSEC & Correlation & $\mathbf{R}^{2}$ & RMSEP \\
\hline \multicolumn{8}{|l|}{ Spectra } \\
\hline Raw & 7 & 0.95 & 0.90 & 6.56 & 0.89 & 0.79 & 9.69 \\
\hline $1^{\text {st }}$ der. & 7 & 0.96 & 0.93 & 5.43 & 0.94 & 0.89 & 6.74 \\
\hline $2^{\text {nd }}$ der. & 7 & 0.97 & 0.95 & 4.58 & 0.95 & 0.91 & 6.17 \\
\hline \multicolumn{8}{|l|}{$\mathbf{L}^{\star} \mathbf{a}^{\star} \mathbf{b}^{\star}$} \\
\hline Raw & 2 & 0.78 & 0.61 & 12.71 & 0.75 & 0.58 & 13.49 \\
\hline \multicolumn{8}{|c|}{ Spectra $+L^{*} a^{*} b^{*}$} \\
\hline Raw & 6 & 0.97 & 0.95 & 4.68 & 0.95 & 0.91 & 6.14 \\
\hline $1^{\text {st }}$ der. & 7 & 0.97 & 0.95 & 4.69 & 0.96 & 0.91 & 5.96 \\
\hline $2^{\text {nd }}$ der. & 7 & 0.96 & 0.93 & 5.44 & 0.95 & 0.90 & 6.56 \\
\hline
\end{tabular}
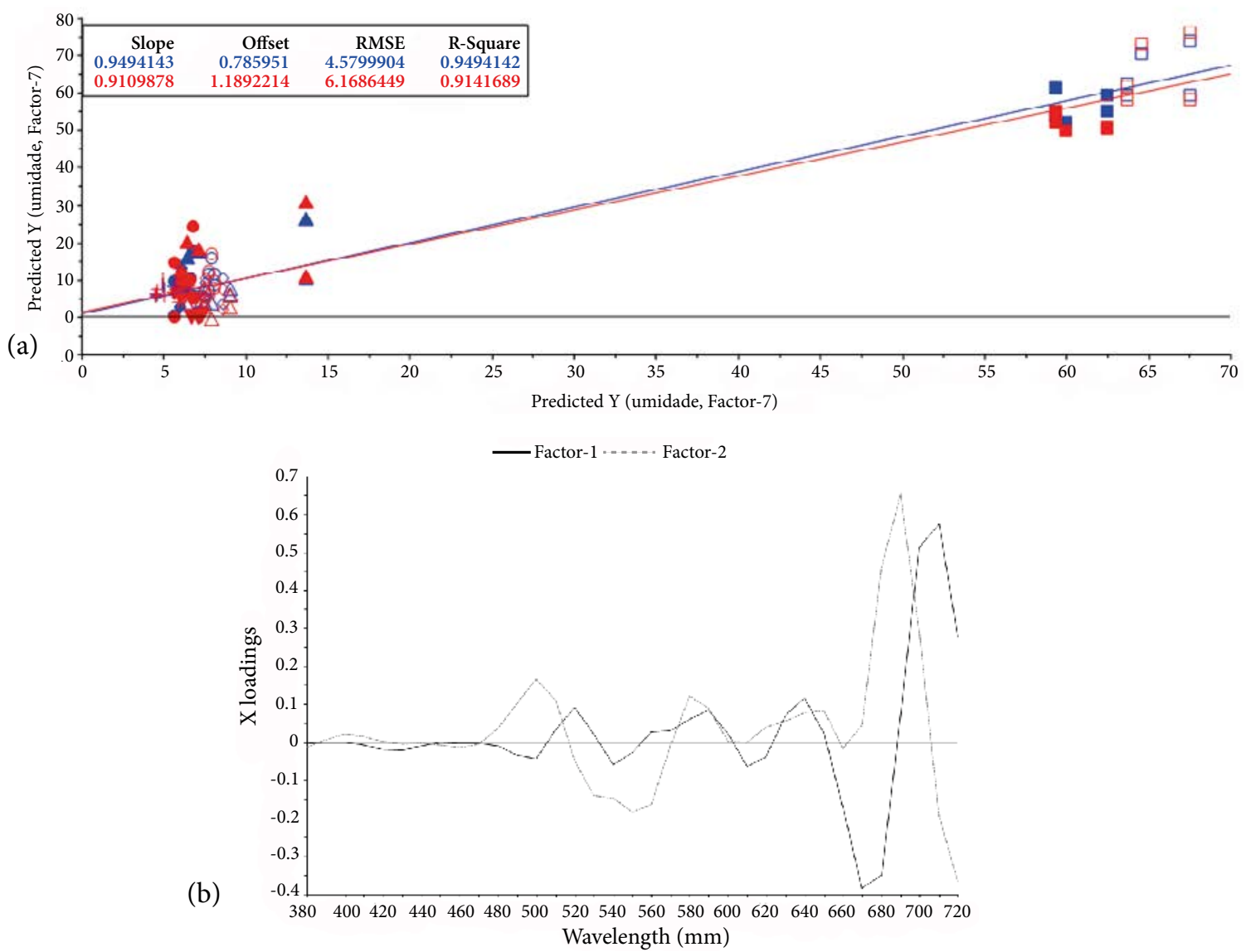

Figure 3. Moisture content predict $\times$ reference (a) and X loading graphs (b) of second derivative spectra of yerba mate in different process stage. 
The use of color parameters to predict moisture content was applied in coffee fruits by Torres et al. (2012) in Colombia, who obtained $\mathrm{R}^{2}=0.77$ for reflectance curve and $\mathrm{R}^{2}=0.56$ for $L^{*}, a^{*}, b^{*}$ parameters. On the other hand, Keskin et al. (2013) reported good correlation between moisture content and parameters $L^{\star}(0.91)$ and $b^{*}(0.85)$ in peanut leaves and suggested the possibility of predicting it based on color data with $\mathrm{R}^{2}=0.88$.

Changes in color parameters during drying were also observed in other material, such as fruits and seeds. In banana and pear, a reduction of lightness was related, indicating darkening of fruits, increase in coordinate $\mathrm{a}^{*}$, in accordance to drying temperature, opposite behavior in coordinate $b^{*}$, with increase in banana samples and decrease in pear samples during drying (Guiné \& Barroca, 2014). Some authors commented that an increase in moisture content resulted in a decrease in parameters $L^{*}$ and $b^{*}$ in paprika powders (Horváth \& Hodúr, 2007). In pink peppercorns, authors described decreasing luminosity, $\mathrm{a}^{*}$ and $\mathrm{b}^{\star}$ parameters with increase in drying temperature (Silva et al., 2017). Influence of time and temperature during roasting process was related with changes in moisture content and color parameters in cocoa beans; the lightness initially increased and then decreased, and parameters $\mathrm{a}^{*}$ and $\mathrm{b}^{*}$ increased with more time and higher temperatures (Zzaman \& Yang, 2013).

Data from a colorimeter or color spectrometer are collected in a fast and non-destructive way, and the preliminary results showed the potential of this technique in predicting moisture content, with heterogeneity in samples, i.e., leaves and fragments, in the yerba mate industry. An external validation must be performed for application in the industrial line or quality control in yerba mate companies, to help the application of yerba mate in a diverse range of final products.

\subsection{Prediction of tannin content}

Mean values of tannin content, on dry basis (Table 4), ranged from 5.58 (green leaves) to $32.04 \mathrm{mg} \mathrm{g}^{-1}$ (pre-drying) in conventional yerba mate samples, and from 3.85 (green leaves) to $22.53 \mathrm{mg} \mathrm{g}^{-1}$ (crumbling) in organic samples.

Table 4. Mean tannin content of yerba mate samples in each process stage.

\begin{tabular}{|c|c|c|c|c|}
\hline \multirow[b]{2}{*}{ Processing stage } & \multicolumn{2}{|c|}{ Conventional yerba mate } & \multicolumn{2}{|c|}{ Organic yerba mate } \\
\hline & $\begin{array}{c}\text { Tannin Content } \\
\left(\mathrm{mg} \mathrm{g}^{-1}\right)\end{array}$ & Standard deviation & $\begin{array}{l}\text { Tannin Content } \\
\left(\mathbf{m g ~ g}^{-1}\right)\end{array}$ & Standard deviation \\
\hline Green leaves & 5.58 & 1.1 & 3.85 & 0.4 \\
\hline Bleaching & 23.46 & 2.0 & 9.67 & 2.2 \\
\hline Pre-drying & 32.04 & 1.8 & 15.86 & 1.6 \\
\hline Drying & 29.43 & 3.5 & 14.71 & 0.7 \\
\hline Crumbling & 22.13 & 3.7 & 22.53 & 0.3 \\
\hline Natural Storage & 22.54 & 3.2 & 19.57 & 2.5 \\
\hline Force d Storage & 18.52 & 1.4 & \multicolumn{2}{|c|}{ Not applicable } \\
\hline
\end{tabular}

Higher tannin content was observed in stages after bleaching, resulting from high temperature applied in process, and low moisture content of yerba mate in these stages. Dartora et al. (2011) showed that yerba mate exposed to sunlight had higher content of bioactive compounds when compared with samples grown under shade. This factor can explain the results observed in our study: conventional yerba mate is related to leaves located predominantly in open regions (sun) and organic yerba mate is grown in shade regions.

Data from color parameters $\left(\mathrm{L}^{\star} \mathrm{a}^{*} \mathrm{~b}^{\star}\right)$ and reflectance spectra (Figure 4) were applied to a Partial Least Square analysis to predict tannin content in different stage of processing. Cross validation was evaluated with original data, first and second derivative of Savitzky-Golay (Table 5).

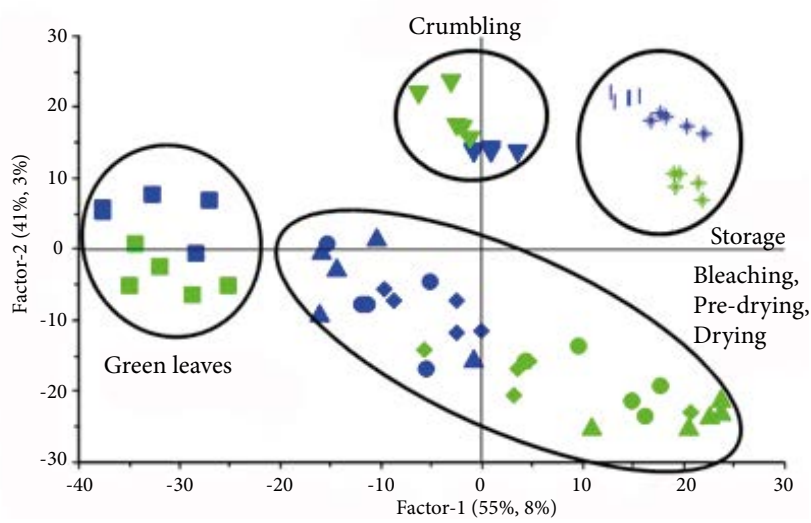

Figure 4. PLS graphic from $L^{*} a^{*} b^{*}$ plus reflectance spectra versus tannin content of conventional (blue) and organic (green) yerba mate samples. 
Table 5. PLS model for tannin content prediction in yerba mate samples (conventional and organic) based on color parameters.

\begin{tabular}{|c|c|c|c|c|c|c|c|}
\hline \multirow[t]{2}{*}{ Data } & \multirow{2}{*}{$\begin{array}{c}\text { PC } \\
\text { number }\end{array}$} & \multicolumn{3}{|c|}{ Calibration } & \multicolumn{3}{|c|}{ Validation } \\
\hline & & Correlation & $\mathbf{R}^{2}$ & RMSEC & Correlation & $\mathbf{R}^{2}$ & RMSEP \\
\hline \multicolumn{8}{|l|}{ Spectra } \\
\hline Raw & 5 & 0.71 & 0.50 & 5.90 & 0.60 & 0.39 & 6.71 \\
\hline $1^{\text {st }}$ der. & 7 & 0.83 & 0.69 & 4.65 & 0.71 & 0.51 & 5.99 \\
\hline $2^{\text {nd }}$ der. & 7 & 0.85 & 0.72 & 4.43 & 0.75 & 0.59 & 5.57 \\
\hline \multicolumn{8}{|l|}{$\mathbf{L}^{*} \mathbf{a}^{*} \mathbf{b}^{*}$} \\
\hline Raw & 2 & 0.36 & 0.13 & 7.78 & 0.23 & 0.04 & 8.18 \\
\hline \multicolumn{8}{|c|}{ Spectra $+\mathbf{L}^{\star} \mathbf{a}^{\star} \mathbf{b}^{\star}$} \\
\hline Raw & 7 & 0.87 & 0.76 & 4.10 & 0.78 & 0.62 & 5.22 \\
\hline $1^{\text {st }}$ der. & 7 & 0.86 & 0.73 & 4.31 & 0.75 & 0.58 & 5.59 \\
\hline $2^{\text {nd }}$ der. & 7 & 0.80 & 0.64 & 4.99 & 0.70 & 0.49 & 6.05 \\
\hline \multicolumn{8}{|c|}{ Spectra $(590-700 \mathrm{~nm})+\mathbf{b}^{*}$} \\
\hline Raw & 7 & 0.68 & 0.90 & 6.10 & 0.55 & 0.86 & 7.31 \\
\hline $1^{\text {st }}$ der. & 7 & 0.80 & 0.93 & 5.08 & 0.75 & 0.92 & 5.63 \\
\hline $2^{\text {nd }}$ der. & 6 & 0.80 & 0.93 & 5.01 & 0.76 & 0.92 & 5.57 \\
\hline
\end{tabular}

Data for model building were obtained from two groups of plantations, organic and conventional, and due to different stages, tannin content ranged from 3.85\% to $32.04 \%$. Better results were found for the second derivative of reflectance spectra in the range 590-700 nm plus chromatic coordinate $\mathrm{b}^{*}$, responsible for red-brown color, with $\mathrm{R}^{2}=0.92$ on validation and an error of $5.5 \%$ in a range of $3-32 \%$ tannin content. Regression (Figure 5a) shows the distinction of all process stage without emphasis in none of them. By observing loading graphs (Figure 5b), it is possible to verify wavenumbers with more influence in it, region from 590-610 nm and 630-650 nm, related to orange and brown.

The literature does not report the application of color parameters to predict tannin content in yerba mate, but the relation with some chemical compounds in other material can be verified: the presence of tannin in wines resulted in lower $L^{*}$ and was related to phenolic compounds and higher contents of anthocyanins by Alcalde-Eon et al. (2014), and also good relationship from parameters $\mathrm{L}^{\star}$ and $\mathrm{a}^{\star}$ to phenolic contents were described by Esparza et al. (2009), who demonstrated these parameters can give information about wine quality.
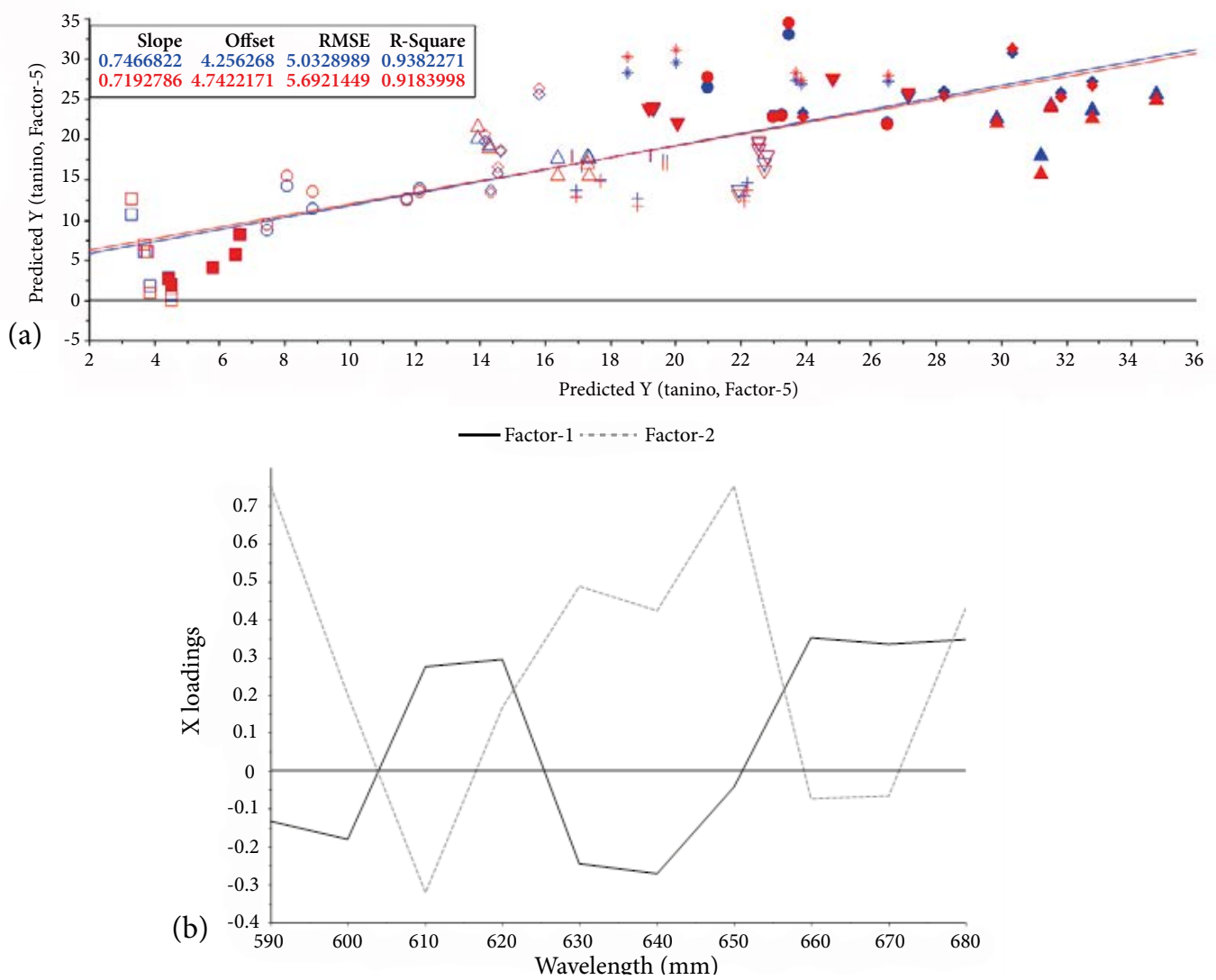

Figure 5. Tannin content predict $\times$ reference $(\mathrm{a})$ and X loading graphs (b) of second derivative spectra of yerba mate in different process stage. 
In Mexican serviceberry fruits, a positive correlation between total phenols content and luminosity $\left(\mathrm{L}^{*}\right)$ was verified, and also a positive correlation of chroma $\left(\mathrm{C}^{*}\right.$, estimated in base of $\mathrm{a}^{\star}$ and $\mathrm{b}^{\star}$ parameters) and percentage of tannins and total phenols were obtained (Herrera-Hernández et al., 2013). The number of phenolic compounds was also significantly correlated with the color of the different melanoidin coffee populations $(\mathrm{r}=0.782, p<0.05)$ by Coelho et al. $(2014)$.

In sugarcane juice, changes in $\mathrm{a}^{*}$ parameter due to maturity stages were related to tannin content: high tannin content resulted in high $\mathrm{a}^{*}$ at the early stage of maturity, and a decrease in tannin content was accompanied by a decrease in $\mathrm{a}^{*}$ value (Qudsieh et al., 2002). Moreover, a strong relationship between tannin and color parameters in sorghum grain was obtained by regression and ANN models by Sedghi et al. (2012), with $\mathrm{R}^{2}$ of 0.88 in regression and 0.98 in ANN models.

On the other hand, Marin et al. (2015), when evaluating lettuce leaves, reported that it is very difficult to find a good correlation between color parameters and pigment content in leaves because it is influenced by anthocyanin and other phenolic compounds, and also by the amount and distribution of chlorophylls and carotenoids.

Color parameters and spectra are influenced by moisture content, but in the same way, are related to tannin content, since the substance "tannin" is red-brown and tend to darken the samples and its reflectance spectra. An external validation must be performed for application in the industrial line or quality control in yerba mate companies, but data collected in a fast and non-destructive way, and the preliminary results showed the potential of this technique in predicting the tannin content.

\section{CONCLUSIONS}

Color parameters and reflectance spectra can be applied for a preliminary evaluation of moisture and tannin content in the yerba mate industry, contributing for the quality control of samples. For moisture content, reflectance curve can be applied with $\mathrm{R}^{2} \geq 0.9$. For tannin content, the sum of $\mathrm{b}^{*}$ parameter and spectra in region $590-700 \mathrm{~nm}$ are recommended. Studies with more samples and different range of moisture and tannin content is recommended to adjust models before employing them in the industry.

\section{SUBMISSION STATUS}

Received: 1 Mar. 2018

Accepted: 13 Dec. 2018

Associate editor: João Vicente de Figueiredo Latorraca

(D) 0000-0002-5969-5199

\section{CORRESPONDENCE TO}

\section{Silvana Nisgoski}

Av. Pref. Lothário Meissner, 632, CEP 80210-170, Curitiba, PR, Brasil e-mail: nisgoski@ufpr.br

\section{FINANCIAL SUPPORT}

Coordenação de Aperfeiçoamento de Pessoal de Nível Superior (CAPES).

\section{REFERENCES}

Alcalde-Eon C, García-Estévez I, Ferreras-Charro R, Rivas-Gonzalo JC, Ferrer-Gallego R, Escribano-Bailón MT. Adding oenological tannin vs. overripe grapes: effect on the phenolic composition of red wines. Journal of Food Composition and Analysis 2014; 34(1): 99-113. 10.1016/j.jfca.2014.01.004

Alvares CA, Stape JL, Sentelhas PC, Gonçalves JLM, Sparovek G. Köppen's climate classification map for Brazil. Meteorologische Zeitschrift 2013; 22(6): 711-728. 10.1127/0941-2948/2013/0507

Association of Official Analytical Chemists - AOAC. Official methods of the AOAC International. 18th ed. Maryland; 2005.

Blum-Silva CH, Chaves VC, Schenkel EP, Coelho GC, Reginatto $\mathrm{FH}$. The influence of leaf age on methylxanthines, total phenolic content, and free radical scavenging capacity of Ilex paraguariensis aqueous extracts. Revista Brasileira de Farmacognosia 2015; 25(1): 1-6. 10.1016/j.bjp.2015.01.002

Burris K, Harte F, Davidson M, Stewart N Jr, Zivanovic S. Composition and bioactive properties of yerba mate (Ilex paraguariensis A. St.-Hill.): a review. Chilean Journal of Agricultural Research 2012; 72(2): 268-274.

Cabral-Malheiros G, Hecktheuer LHR, Canto MW, Balsamo GM. $\mathrm{O}$ tempo e o tipo de embalagem sobre a erva-mate tipo chimarrão durante armazenagem em condições ambientais. Ciência Rural 2010; 40(3): 654-660. 10.1590/S0103-84782010005000028

Caron BO, Santos DR, Schmidt D, Basso CJ, Behling A, Eloy E, Bamberg R. Biomassa e acúmulo de nutrientes em Ilex paraguariensis A. St. Hil. Ciência Florestal 2014; 24(2): 267-276. $10.5902 / 1980509814565$

Ceni GC, Baldissera EM, Primo MS, Antunes OAC, Dariva C, Oliveira JV, Oliveira D. Influence of application of microwave energy on quality parameters of mate tea leaves (Ilex paraguariensis St.Hill.). Food Technology and Biotechnology 2009; 47(2): 221-226.

Coelho C, Ribeiro M, Cruz ACS, Domingues MRM, Coimbra MAC, Bunzel M, Nunes FM. Nature of phenolic compounds in coffee melanoidins. Journal of Agricultural Food and Chemistry 2014; 62(31): 7843-7853. 10.1021/jf501510d

Dartora N, Souza LM, Santana-Filho AP, Iacomini M, Valduga AT, Gorin PAJ, Sassaki GL. UPLC-PDA-MS evaluation of bioactive compounds from leaves of Ilex paraguariensis with different growth conditions, treatments and ageing. Food Chemistry 2011; 129(4): 1453-1461. 10.1016/j.foodchem.2011.05.112

Esparza I, Santamaría C, Calvo I, Fernández JM. Significance of CIELAB parameters in the routine analysis of red wines. CyTA: Journal of Food 2009; 7(3): 189-199. 10.1080/19476330903068001 
Guiné RPF, Barroca MJ. Evaluation of the browning kinetics for bananas and pears submitted to convective drying. Current Biochemical Engineering 2014; 1(2): 165-172. 10.2174/221271190 1666131203000741

Hao D, Gu X, Xiao P, Liang Z, Xu L, Peng Y. Research progress in the phytochemistry and biology of Ilex pharmaceutical resources. Acta Pharmaceutica Sinica B 2013; 3(1): 8-19. 10.1016/j.apsb.2012.12.008

Herrera-Hernández MG, Núñez-Colín CA, Guzmán-Maldonado SH, Hernández-Martínez MÁ. Contents of some antioxidant compounds at three stages of maturity of the Mexican serviceberry fruits (Malacomeles denticulata) in two localities. Revista Chapingo Série Horticultura 2013; 19(4): 45-57.

Horváth $\mathrm{ZH}$, Hodúr C. Colour of paprika powders with different moisture content. International Agrophysics 2007; 21(1): 67-72.

İnanç AL. Chlorophyll: structural properties, health benefits and its occurrence in virgin olive oils. Akademik Gida 2011; 9(2): 26-32.

Jin L, Li XB, Tian DQ, Fang XP, Yu YM, Zhu HQ et al. Antioxidant properties and color parameters of herbal teas in China. Industrial Crops and Products 2016; 87: 198-209.

Keskin M, Karanlik S, Görücü Keskin S, Soysal Y. Utilization of color parameters to estimate moisture content and nutrient levels of peanut leaves. Turkish Journal of Agriculture and Forestry 2013; 37(5): 604-612.

Marin A, Ferreres F, Barberá GG, Gil MI. Weather variability influences color and phenolic content of pigmented baby leaf lettuces throughout the season. Journal of Agricultural and Food Chemistry 2015; 63(6): 1673-1681.

Martins GBC, Sucupira RR, Suarez PAZ. A química e as cores. Revista Virtual de Química 2015; 7(4): 1508-1534. 10.5935/19846835.20150082

Ollinger SV. Sources of variability in canopy reflectance and the convergent properties of plants. New Phytologist 2010; 189(2): 375-394. 10.1111/j.1469-8137.2010.03536.x

Peñuelas J, Filella I. Visible and near infrared reflectance techniques for diagnosing plant physiological status. Trends in Plant Science 1998; 3(4): 151-156. 10.1016/S1360-1385(98)01213-8

Polidoro AS, Scapin E, Malmann M, Carmo JU, Machado ME, Caramão EB, Jacques RA. Characterization of volatile fractions in green mate and mate leaves (Ilex paraguariensis A. St. Hil.) by comprehensive two-dimensional gas chromatography coupled to time-of-flight mass spectrometry (GC $\times \mathrm{GC} / \mathrm{TOFMS})$. Microchemical Journal 2016; 128: 118-127. 10.1016/j.microc.2016.03.019

Prince ML, Scoyoc SV, Butler LG. A critical evaluation of the vanillin reaction as an assay for tannin in sorghum grain. Journal of Agricultural and Food Chemistry 1978; 26(5): 1214-1218. 10.1021/ jf60219a031

Qudsieh HYM, Yusof S, Osman A, Rahman RA. Effect of maturity on chlorophyll, tannin, color, and polyphenol oxidase (PPO) activity of sugarcane juice (Saccharum officinarum var. Yellow Cane). Journal of Agricultural and Food Chemistry2002; 50(6): 1615-1618. 10.1021/jf010959l

Ramallo LA, Lovera NN, Schmalko ME. Effect of the application of intermittent drying on Ilex paraguariensis quality and drying kinetics. Journal of Food Engineering 2010; 97(2): 188-193. 10.1016/j. jfoodeng.2009.10.008

Richardson AD, Reeves JB III, Gregoire TG. Multivariate analyses of visible/near infrared (VIS/NIR) absorbance spectra reveal underlying spectral differences among dried, ground conifer needle sample from different growth environments. New Phytologist 2003; 161(1): 291-301. 10.1046/j.1469-8137.2003.00913.x

Roderjan CV, Galvão F, Kuniyoshi YS, Hatschbach GG. As unidades fitogeográficas do estado do Paraná. Ciência e Ambiente 2002; 24: 75-92.

Schmalko ME, Alzamora SM. Color, chlorophyll, caffeine, and water content variation during yerba mate processing. Drying Technology 2001; 19(3-4): 599-610. 10.1081/DRT-100103937

Scipioni GP, Argüello BV, Schmalko ME. The effect of $\mathrm{Mg}^{2+}, \mathrm{Cu}^{2+}$ and $\mathrm{Zn}^{2+}$ pre-treatment on the color of yerba mate (Ilex paraguariensis) leaves. Brazilian Archives of Biology and Technology 2010; 53(6): 1497-1502. 10.1590/S1516-89132010000600027

Sedghi M, Golian A, Soleimani-Roodi P, Ahmadi A, Aami-Azghadi M. Relationship between color and tannin content in Sorghum Grain: application of image analysis and Artificial Neural Network. Brazilian Journal of Poultry Science 2012; 14(1): 57-62. 10.1590/ S1516-635X2012000100010

Silva BG, Fileti AMF, Foglio MA, Rosa PTV, Taranto OP. Effects of different drying conditions on key quality parameters of pink peppercorns (Schinus terebinthifolius Raddi). Journal of Food Quality 2017; 2017: 3152797. 10.1155/2017/3152797

Sims DA, Gamon JA. Relationships between leaf pigment content and spectral reflectance across a wide range of species, leaf structures and developmental stages. Remote Sensing of Environment 2002; 81(2-3): 337-354. 10.1016/S0034-4257(02)00010-X

Tan SM, Luo RM, Zhou YP, Xu H, Song DD, Ze T et al. Boosting partial least-squares discriminant analysis with application to near infrared spectroscopic tea variety discrimination. Journal of Chemometrics 2012; 26(1-2): 34-39. 10.1002/cem.1423

Torres IDA, Herrera JJC, Tascón CEO. Physical and mechanical properties correlation of coffee fruit (Coffea arabica) during its ripening. Dyna 2012; 79(172): 148-155.

Valduga AT, Gonçalves IL, Borges ACP, Mielniczki-Pereira AA, Picolo AP. Cytotoxic/antioxidant activity and sensorial acceptance of yerba-mate development by oxidation process. Acta Scientiarum Technology 2016; 38(1): 115-121. 10.4025/ actascitechnol.v38i1.26033

Valduga E, Javornik G, Sordi M, Rezende DF. Nota prévia: avaliação das características de qualidade da erva-mate (chimarrão) acondicionada em diferentes embalagens. Brazilian Journal of Food Technology 2005; 8(2): 99-105.

Xie LJ, Ying YB, Ying TJ. Quantification of chlorophyll content and classification of non-transgenic and transgenic tomato leaves using visible/ near infrared diffuse reflectance spectroscopy. Journal of Agricultural and Food Chemistry 2007; 55(12): 4645-4650. 10.1021/jf063664m

Zielinski AAF, Haminiuk CWI, Alberti A, Nogueira A, Demiate IM, Granato D. A comparative study of the phenolic compounds and the in vitro antioxidant activity of different Brazilian teas using multivariate statistical techniques. Food Research International 2014; 60: 246-254. 10.1016/j.foodres.2013.09.010

Zzaman W, Yang TA. Moisture, color and texture changes in cocoa seeds during superheated steam roasting. Journal of Applied Sciences Research 2013; 9(1): 1-7. 